\title{
PENINGKATAN KEMAMPUAN BERPIKIR KRITIS MAHASISWA MELALUI METODE PENEMUAN TERBIMBING BERBANTUAN SOFTWARE GEOGEBRA PADA MATA KULIAH KALKULUS PEUBAH BANYAK DI FKIP UMSU
}

\author{
Ismail Hanif Batubara \\ Program Studi Pendidikan Matematika Universitas Muhammadiyah Sumatera Utara \\ ismailhanif@umsu.ac.id
}

\begin{abstract}
The purpose of this study was to find out: (1) Is the increase in mathematical critical thinking abilities of students given the guided discovery method assisted by Geogebra software higher than students who were given guided discovery method learning without Geogebra software, (2) Are their interactions between learning with students 'initial mathematical abilities towards improving students' critical thinking skills. This research is a quasi-experimental study. The population of this study is that all classes in the fourth-semester mathematics education study program are approximately 120 people. Randomly, two classes were chosen from four classes. The experimental class was treated with Geogebra assisted guided discovery methods and the control class was treated with a guided discovery method without the help of Geogebra. Data analysis was performed by analysis of two-way variance (ANAVA). The results showed (1) Improvement of mathematical critical thinking skills of groups of students who obtained guided discovery method learning using GeoGebra software was higher than the group of students who received learning through guided discovery methods without GeoGebra software. (2) There is no interaction between the learning model and the initial ability of students in improving students' critical thinking skills in mathematics.
\end{abstract}

Keywords: Critical Thinking Ability, Guided Discovery Method, Geogebra

\begin{abstract}
Abstrak. Tujuan dari penelitian ini adalah untuk mengetahui: (1) Apakah peningkatan kemampuan berpikir kritis matematik mahasiswa yang diberi pembelajaran metode penemuan terbimbing berbantuan software Geogebra lebih tinggi dari pada mahasiswa yang diberi pembelajaran metode penemuan terbimbing tanpa software Geogebra, (2) Apakah terdapat interaksi antara pembelajaran dengan kemampuan awal matematik mahasiswa terhadap peningkatan kemampuan berpikir kritis matematik mahasiswa. Penelitian ini merupakan penelitian quasi eksperimen. Populasi dari penelitian ini adalah seluruh kelas prodi pendidikan matematika semester empat yang berjumlah kurang lebih 120 orang. Secara acak, dipilih dua kelas dari empat kelas. Kelas eksperimen diberi perlakuan metode penemuan terbimbing berbantuan Geogebra dan kelas control diberi perlakuan metode penemuan terbimbing tanpa bantuan Geogebra. Analisis data dilakukan dengan analisis varians (ANAVA) dua jalur. Hasil penelitian menunjukkan (1) Peningkatan kemampuan berpikir kritis matematis kelompok mahasiswa yang memperoleh pembelajaran metode penemuan terbimbing dengan menggunakan software Geogebra lebih tinggi dibandingkan dengan kelompok mahasiswa yang memperoleh pembelajaran melalui metode penemuan terbimbing tanpa software Geogebra. (2) Tidak terdapat interaksi antara model pembelajaran dengan kemampuan awal mahasiswa terhadap peningkatan kemampuan berpikir kritis matematik mahasiswa.
\end{abstract}

Kata Kunci: Kemampuan Berpikir Kritis, Metode Penemuan Terbimbing, Geogebra

\section{PENDAHULUAN}

Matematika dengan berbagai peranannya menjadikannya sebagai ilmu yang sangat penting, dan salah satu peranan matematika adalah sebagai alat berpikir untuk mengantarkan peserta didik memahami konsep matematika yang sedang dipelajarinya. Kemampuan pemahaman matematis serta berpikir kritis sangat dibutuhkan oleh mahasiswa dalam menarik sebuah kesimpulan sehingga seorang peserta didik mampu menyelesaikan persoalan-persoalan matematika. Namun fakta berkata lain bahwa sering kali mahasiswa 
salah langkah dalam mengambil berbagai keputusan dengan tidak memahami konsep yang sebenarnya dan tidak diiringi dengan berpikir kritis.

Sebagai contoh banyak mahasiswa yang tidak mampu dalam menggambarkan sebuah grafik dari fungsi yang diberikan. Belum lagi materi- materi lain seperti integral, barisan dan deret dan lain sebagainya, masih banyak mahasiswa yang masih ragu dan bimbang dalam menyelesaikan dan menentukan solusi-solusi dari permasalahan-permasalahan yang muncul. Padahal untuk menjadi seorang guru, materi-materi seperti di atas haruslah bisa dikuasai oleh seseorang yang menyandang profesi sebagai guru. Kurangnya kemampuan berpikir kritis mahasiswa terhadap materi tersebut menjadi sebuah dilema tersendiri bagi mahasiswa. Santrock (Irawati, 2014:208) menyatakan bahwa kemampuan berpikir kritis adalah aspek kunci dari pembelajaran, salah satu tujuan pengajaran yang penting adalah membantu siswa memahami konsep utama dan dalam suatu subjek bukan hanya mengingat fakta-fakta yang terpisah-pisah. Ketidaksesuaian antara fakta dengan yang diharapkan saat ini menjadi latarbelakang penulis dalam menuliskan laporan penelitian ini.

Penerapan pembelajaran penemuan terbimbing merupakan salah satu dari solusi permasalahan di atas. Shadiq (2009:12) menjelaskan bahwa pembelajaran penemuan terbimbing merupakan suatu pembelajaran dimana siswa diberikan suatu situasi atau masalah, yang selanjutnya melakukan pengumpulan data, membuat dugaan (konjektur), mencoba-coba (trial and error), mencari dan menemukan keteraturan (pola), menggeneralisasi atau menyusun rumus beserta bentuk umum, membuktikan benar tidaknya dugaannya itu. Oleh karena itu pembelajaran dengan penemuan terbimbing memungkinkan siswa untuk membangun sendiri pengetahuannya melalui kegiatankegiatan yang dirancang, sehingga membuat suatu kesimpulan berdasarkan pemahaman siswa.

Bantuan ICT seperti software Geogebra juga dapat menarik minat mahasiswa terhadap pembelajaran matematika. Karnasih (2008) juga mengatakan bahwa "Software Geogebra, Geogebra leads the way in the use of dependent, selectable mathematics objescts to help student get to grips with the principles of probability and statistics, graph, coordinat geometry, in both $2 D$ and $3 D$ ". Pendapat ahli tersebut menjelaskan bahwa Geogebra dapat membantu siswa untuk memahami materi-materi pembelajaran seperti probabilitas, statistik, dan geometri karena Geogebra memiliki lembar kerja 2D dan 3D. Dengan demikian dapat disimpulkan bahwa penggunaan software Geogebra dapat membantu para pendidik dan anak didik dalam proses belajar dan pembelajaran di sekolah.

Berdasarkan permasalahan di atas, serta beberapa solusi yang disebutkan sebelumnya peneliti mencoba untuk menggabungkan pembelajaran penemuan terbimbing dengan media teknologi komputer (Geogebra), untuk meningkatkan kemampuan berpikir kritis matematis mahasiswa. Tujuan artikel ini adalah untuk mengetahui: (1) Apakah peningkatan kemampuan berpikir kritis matematik mahasiswa yang diberi pembelajaran metode penemuan terbimbing berbantuan software Geogebra lebih tinggi dari pada mahasiswa yang diberi pembelajaran metode penemuan terbimbing tanpa software Geogebra, (2) Apakah terdapat interaksi antara pembelajaran dengan kemampuan awal matematik mahasiswa terhadap peningkatan kemampuan berpikir kritis matematik mahasiswa

\section{METODE}

Populasi dari penelitian ini adalah seluruh kelas prodi pendidikan matematika semester empat yang berjumlah kurang lebih 120 orang. Sedangkan yang menjadi sampel pada penelitian ini adalah dua kelas yang dipilih dari kelas yang sudah ada pada prodi pendidikan matematika semester empat Fakultas Keguruan dan Ilmu Pendidikan Universitas Muhammadiyah Sumatera Utara tahun ajaran 2018/2019. 
Peningkatan kemampuan berpikir kritis mahasiswa melalui metode penemuan...

Penelitian ini merupakan penelitian quasi eksperiment. Penelitian ini dilakukan dengan metode penemuan terbimbing berbantuan Geogebra. Secara garis besar disimpulkan bahwa penelitian ini dilaksanakan dengan tahapan: (1) Tahap penyusunan perangkat pembelajaran dan instrument penelitian yang meliputi tes awal dan sebagainya (2) Tahap pelaksanaan eksperimen berupa pemberian perlakuan pembelajaran, dan (3) Tahap analisis hasil penelitian. Setiap tahapan didesain sedemikian sehingga diperoleh data yang valid sesuai dengan karakteristik variabel dan tujuan penelitian. Data yang akan dikumpulkan dalam penelitian ini adalah data yang berkaitan dengan hasil belajar mahasiswa yang diambil menggunakan test. Tes dilakukan dengan memberikan soal-soal uraian (essay). Tes yang diberikan berupa soal pretest dan soal post-test.

Pengolahan data diawali dengan menguji persyaratan statistik yang diperlukan sebagai dasar dalam pengujian hipotesis, antara lain adalah uji normalitas data dan uji homogenitas varians. Selanjutnya, dilakukan uji-t, regresi dan korelasi yang disesuaikan dengan permasalahannya. Seluruh perhitungan statistik pada penelitian ini menggunakan bantuan program komputer SPSS.

Hipotesis 1:

Untuk menguji peningkatan kemampuan berpikir kritis matematis siswa.

$H_{0}: \mu_{x}=\mu_{y}$

$H_{a}: \mu_{x} \neq \mu_{y}$

Keterangan:

$\mu_{x}$ : Peningkatan kemampuan berpikir kritis matematik mahasiswa yang diajarkan dengan metode penemuan terbimbing berbantuan Geogebra.

$\mu_{y}$ : Peningkatan kemampuan berpikir kritis matematik yang diajarkan dengan metode penemuan terbimbing tanpa Geogebra.

Untuk menguji hipotesis ini digunakan rumus uji t dengan bantuan SPSS dengan kriteria pengujiannnya adalah tolak $H_{0}$ jika $t_{\text {tabel }}<t_{\text {hitung }}$ dan terima $H_{0}$ untuk kondisi lainnya dengan taraf signifikansi yang telah ditentukan.

Hipotesis 2:

Untuk menguji interaksi antara pembelajaran dan kemampuan awal matematik mahasiswa terhadap peningkatan kemampuan berpikir kritis mahasiswa.

$H_{0}: \mu_{11}-\mu_{12}=\mu_{21}-\mu_{22}=\mu_{31}-\mu_{32}$

$H_{a}$ : Sedikitnya ada satu selisih rata-rata kemampuan berpikir kritis matematik mahasiswa yang berbeda dari yang lainnya

Keterangan:

$\mu_{11}$ :Kelompok tinggi kemampuan awal matematik mahasiswa yang diajarkan dengan metode penemuan terbimbing berbantuan Geogebra untuk peningkatan kemampuan berpikir kritis matematik mahasiswa.

$\mu_{12}$ :Kelompok tinggi kemampuan awal matematik mahasiswa yang diajarkan dengan metode penemuan terbimbing tanpa Geogebra untuk peningkatan kemampuan berpikir kritis matematik mahasiswa.

Untuk menguji hipotesis 2 digunakan uji statistik anava dua jalur dengan menggunakan program SPSS. Kriteria pengujiannya adalah terima $H_{0}$ jika nilai signifikansi (sig) lebih besar dari 0,05 dalam hal lainnya jika nilai signifikansi (sig) lebih kecil dari 0,05 $H_{0}$ ditolak. 
HASIL DAN PEMBAHASAN

Deskripsi Hasil $N$-gain Kemampuan Berpikir Kritis Matematika di Kelas Eksperimen I dan Kelas eksperiment II

Tabel 1. Hasil $N$-gain Kemampuan Berpikir Kritis Matematika Pada Kedua Kelas Sampel

\begin{tabular}{ccccc}
\hline Kelas & $\boldsymbol{X}_{\text {maks }}$ & $\boldsymbol{X}_{\min }$ & $\boldsymbol{X}_{\text {rata-rata }}$ & SD \\
\hline Eksperimen I & 1.00 & 0.44 & 0.79 & 0.14 \\
\hline Eksperimen II & 1.00 & 0.45 & 0.66 & 0.15 \\
\hline
\end{tabular}

Agar lebih jelas perbedaannya maka digambarkan dalam diagram batang pada gambar 1 berikut ini.

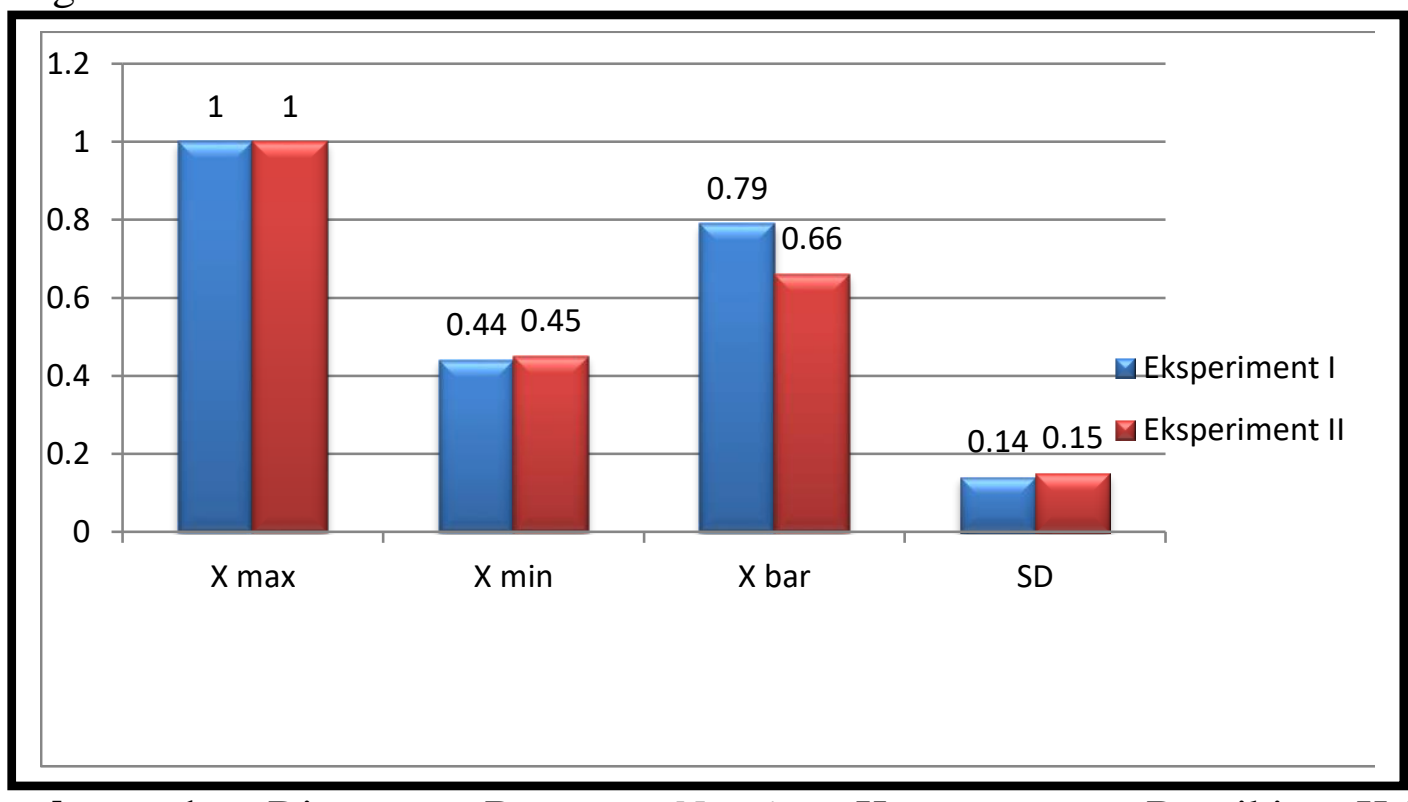

Gambar 1. Diagram Batang $N$-gain Kemampuan Berpikir Kritis Kelas Eksperimen I dan Eksperimen II

Pada Tabel 1 dan gambar 1 di atas terlihat bahwa nilai tertinggi $N$-gain pada kedua kelas ekperimen sebesar 1 . Sedangkan untuk nilai rata-rata $\mathrm{N}$-gain kelas eksperimen I sebesar 0,79 dan kelas eksperimen II sebesar 0,66. Jadi rata-rata $\mathrm{N}$-gain kelas eksperimen I lebih tinggi sedikit dibandingkan rata-rata $N$-gain dikelas eksperiment II. Dari perolehan ini maka selisih rata-rata $\mathrm{N}$-gain antara kelas ekperimen I dan kelas eksperiment II sangat tipis yakni sebesar 0,13 .

\section{Uji Normalitas pada $N$-gain Kedua Kelas}

Hipotesis yang diuji untuk mengetahui normalitas kelompok data $N$-gain kemampuan berpikir kritis matematik adalah:

$H_{0}: f(x)=$ normal

$H_{a}: f(x) \neq$ normal

Tabel 2. Tabel Normalitas $N$-gain Kedua Kelas

Tests of Normality

\begin{tabular}{lcrrrrrr}
\hline & \multicolumn{3}{c}{ Kolmogorov-Smirnov ${ }^{\mathrm{a}}$} & \multicolumn{4}{c}{ Shapiro-Wilk } \\
\cline { 2 - 8 } & Statistic & $\mathrm{df}$ & \multicolumn{1}{c}{ Sig. } & Statistic & $\mathrm{df}$ & \multicolumn{1}{c}{ Sig. } \\
\hline EKS1 & .109 & 30 & $.200^{*}$ & .947 & 30 & .138 \\
EKS2 & .159 & 30 & .051 & .949 & 30 & .161 \\
\hline
\end{tabular}

a. Lilliefors Significance Correction

*. This is a lower bound of the true significance. 
Peningkatan kemampuan berpikir kritis mahasiswa melalui metode penemuan...

Dari hasil uji Kolmogorov-Smirnov test tersebut, diketahui bahwa nilai Signifikansi kelas eksperimen I sebesar 0.200 sedangkan kelas eksperimen II sebesar 0.51. Karena nilai signifikansi kelas eksperimen I (0.200) maka sig eks I $>\alpha(0,2000>0,05)$ sehingga data $\mathrm{N}$-gain kelas eksperimen I berdistribusi normal, dan untuk kelas eksperimen II nilai sig > $\alpha(0.51>0,05)$, artinya data $N$-gain kelas eksperimen II juga berdistribusi normal. Jadi data $\mathrm{N}$-gain kelas eksperimen I dan kelas eksperimen II berasal dari data berdistribusi normal. Dengan demikian data $N$-gain kemampuan berpikir kritis secara keseluruhan dapat disimpulkan berdistribusi Normal.

\section{Uji Homogenitas pada $N$-gain Hasil Belajar}

Setalah melalui tahap uji normalitas, data $N$-gain juga harus melalui tahap uji Homogenitas. Pada penelitian ini uji homogenitas menggunakan uji F. Hipotesis yang diuji untuk mengetahui homogenitas kelompok data $N$-gain hasil belajar adalah:

$H_{0}: \sigma_{1}^{2}=\sigma_{2}^{2}$

$H_{a}: \sigma_{1}^{2} \neq \sigma_{2}^{2}$

Keterangan:

$\sigma_{1}^{2}$ adalah varians skor kelompok model pembelajaran berbasis masalah

$\sigma_{2}^{2}$ adalah varians skor kelompok kelas control.

Tabel 3. Tabel Hasil Uji Homogenitas $N$-gain Kedua Kelas

Test of Homogeneity of Variances

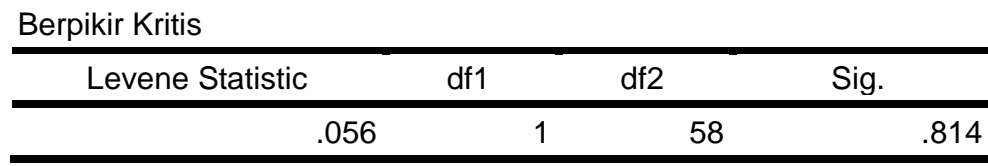

Dari hasil uji levene di atas, diketahui bahwa untuk pengujian homogenitas dengan uji Levene nilai sig $>\alpha(0,841>0,05)$ dan $\mathrm{F}$ hitung sehingga hipotesis nol diterima yang berarti semua populasi mempunyai varians yang sama/homogen. Dengan demikian data $N$ gain kemampuan berpikir kritis secara keseluruhan dapat disimpulkan memiliki varians yang sama atau homogen. Berdasarkan pengujian Normalitas dan homogenitas di atas disimpulkan bahwa data $N$-gain kemampuan berpikir kritis berdistribusi normal dan memiliki varians yang sama.

\section{Uji Hipotesis Pertama}

Dari hasil uji prasyarat analisis yakni uji normalitas dan homogenitas menunjukkan bahwa data $\mathrm{N}$-gain kemampuan berpikir kritis siswa berdistribusi normal dan varians dari setiap kelompok data sama, maka untuk menganalisisnya menggunakan uji statistik parametrik yakni menggunakan uji t yang dijelaskan pada tabel berikut.

Tabel 4. Hasil Uji t Kemampuan Berpikir Kritis Matematik

Independent Samples Test

\begin{tabular}{|c|c|c|c|c|c|c|c|c|c|c|}
\hline & & \multicolumn{4}{|c|}{$\begin{array}{c}\text { Levene's Test for Equality of } \\
\text { Variances }\end{array}$} & \multicolumn{5}{|c|}{ t-test for Equality of Means } \\
\hline & & \multirow[t]{2}{*}{$\mathrm{F}$} & \multirow[t]{2}{*}{ Sig. } & \multirow[t]{2}{*}{$\mathrm{T}$} & \multirow[t]{2}{*}{ df } & \multirow[t]{2}{*}{$\begin{array}{c}\text { Sig. } \\
(2- \\
\text { tailed })\end{array}$} & \multirow[t]{2}{*}{$\begin{array}{c}\text { Mean } \\
\text { Difference }\end{array}$} & \multirow[t]{2}{*}{$\begin{array}{l}\text { Std. Error } \\
\text { Difference }\end{array}$} & \multicolumn{2}{|c|}{$\begin{array}{l}95 \% \text { Confidence } \\
\text { Interval of the } \\
\text { Difference }\end{array}$} \\
\hline & & & & & & & & & Lower & Upper \\
\hline \multirow[t]{2}{*}{$\begin{array}{l}\text { Berpikir } \\
\text { Kritis } \\
\text { Matematis }\end{array}$} & $\begin{array}{l}\text { Equal } \\
\text { variances } \\
\text { assumed }\end{array}$ & .056 & .814 & 3.554 & 58 & .001 & .13100 & .03686 & .05721 & .20479 \\
\hline & $\begin{array}{l}\text { Equal } \\
\text { variances not } \\
\text { assumed }\end{array}$ & & & 3.554 & 57.708 & .001 & .13100 & .03686 & .05720 & .20480 \\
\hline
\end{tabular}


Berdasarkan hasil perhitungan pada tabel 4 di atas dengan menggunakan uji t pada taraf signifikansi $\alpha=0,05$ diperoleh thitung sebesar 3.554 dengan nilai signifikansi 0,001 sedangkan $t_{\text {tabel }}$ sebesar 2,00 . Karena thitung $(3,554)>t_{\text {tabel }}(2,00)$ dan nilai signifikansi $(0,001)<\alpha(0,05)$, sehingga $\mathrm{H}_{0}$ ditolak. Maka dapat disimpulkan bahwa peningkatan Kemampuan berpikir kritis matematik mahasiswa yang diajarkan melalui metode pembelajaran penemuan terbimbing berbantuan geogebra lebih tinggi dari pada yang diajarkan melalui metode pembelajaran penemuan terbimbing tanpa geogebra.

\section{Uji Hipotesis Kedua}

Hipotesis yang diajukan untuk di uji dengan uji ANAVA dirumuskan sebagai berikut: $H_{0}: \mu_{11}-\mu_{12}=\mu_{21}-\mu_{22}=\mu_{31}-\mu_{32}$

$H_{a}$ : Sedikitnya ada satu selisih rata-rata kemampuan berpikir kritis matematik mahasiswa yang berbeda dari yang lainnya

Kriteria pengujiannya adalah jika nilai significance (sig) lebih besar dari $\alpha=0,05$. Maka $H_{0}$ diterima, dalam hal lainnya di tolak.

Tabel 5. Hasil Uji Anava Berdasarkan Pembelajaran dan Kategori KAM

\section{Tests of Between-Subjects Effects}

Dependent Variable:gain

\begin{tabular}{lrrrrr}
\hline Source & $\begin{array}{c}\text { Type III Sum of } \\
\text { Squares }\end{array}$ & df & Mean Square & \multicolumn{1}{c}{ F } & \multicolumn{1}{c}{ Sig. } \\
\hline Corrected Model & $.864^{\mathrm{a}}$ & 5 & .173 & 16.226 & .000 \\
Intercept & 28.006 & 1 & 28.006 & $2.629 \mathrm{E} 3$ & .000 \\
Pembelajaran & .291 & 1 & .291 & 27.315 & .000 \\
Kam & .539 & 2 & .269 & 25.288 & .000 \\
pembelajaran * kam & .058 & 2 & .029 & 2.737 & .074 \\
Error & .575 & 54 & .011 & & \\
Total & 33.224 & 60 & & & \\
Corrected Total & 1.440 & 59 & & & \\
\hline
\end{tabular}

a. R Squared $=, 600$ (Adjusted R Squared $=, 563$ )

Dari tabel 5 di atas terlihat bahwa untuk faktor pembelajaran dan KAM, diperoleh nilai signifikansi sebesar 0,74. Karena nilai signifikansi lebih besar dari nilai taraf signikan 0,05, maka Ho diterima, yang berarti tidak terdapat interaksi antara pendekatan pembelajaran dengan kemampuan awal siswa terhadap peningkatan kemampuan Berpikir Kritis matamatik siswa. Jadi, peningkatan kemampuan Berpikir Kritis matematik siswa disebabkan oleh perbedaan pembelajaran yang digunakan bukan karena kemampuan awal matematika siswa. Dengan kata lain, tidak terdapat pengaruh secara bersama yang diberikan oleh pembelajaran dan KAM.

Melihat hasil penelitian yang telah dikemukakan di atas, menunjukkan bahwa metode penemuan terbimbing berbantuan Geogebra secara signifikan lebih baik dalam meningkatkan hasil belajar siswa dibandingkan dengan metode penemuan terbimbing tanpa bantuan Geogebra. Dalam kegiatan pembelajaran ini mahasiswa berkesempatan berinteraksi dengan komunitasnya. Mahasiswa akan saling berbagi ide untuk mengajukan penyelesaian baik di dalam kelompok maupun menyajikan hasil akhirnya di depan kelas. Sehingga mahasiswa dengan mudah dapat menemukan kesalahan-kesalahan pada penyelesaian masalah yang dibuat. Sedangkan bagi mahasiswa berkemampuan tinggi mempunyai kesempatan untuk berlatih menyampaikan ide dan gagasan kepada orang lain dan menghargai pendapat orang lain sehingga sangat memungkinkan dapat menambah pengetahuan mereka. 
Peningkatan kemampuan berpikir kritis mahasiswa melalui metode penemuan...

Namun pada kelas eksperimen kedua yang terjadi tidaklah seperti yang diharapkan. Sebagian besar mahasiswa tidak berupaya maksimum menggunakan segenap kemampuan kognisinya, dan tidak berinteraksi dengan komunitasnya dan mementingkan ego masingmasing. Sehingga mahasiswa bekerja secara individual pada saat menyelesaikan soal. Disamping mahasiswa mementingkan ego masing-masing ,mahasiswa lainnya bergantung pada dosen dalam menyelesaikan soal, sehingga sifat pengulangan meniru dan menghafal sebagai pembentukan pengetahuan dengan dosen sebagai model dan sumber belajar juga terjadi di kelas ini. Dengan demikian, peran aktif mahasiswa serta interaksi yang terjadi sangat minim sekali.

Hal yang membuat tidak terdapat interaksi antara pembelajaran dengan tingkat kemampuan awal matematika mahasiswa terhadap peningkatan hasil belajar mahasiswa adalah faktor pemberian pembelajaran yang relatif sama antar kedua kelas sehingga kemampuan awal matematik siswa tidak memberi pengaruh secara bersamaan terhadap peningkatan hasil belajar mahasiswa.

Berdasarkan temuan di atas dapat disimpulkan bahwa penggunaan metode penemuan terbimbing berbantuan Geogebra lebih baik dibandingkan dengan metode penemuan terbimbing tanpa bantuan Geogebra. Hasil temuan ini sejalan dengan penelitian yang dilakukan oleh Afriati (2011), yang menyatakan bahwa siswa yang mendapat penemuan terbimbing berbantuan software autograph lebih menunjukkan kektifan belajar dari siswa yang mendapat pendekatan biasa. Batubara (2017:103) menyatakan bahwa Peningkatan kemampuan pemahaman konsep matematik siswa yang diajarkan melalui pembelajaran berbasis masalah berbantuan autograph lebih tinggi dari pada yang diajarkan melalui pembelajaran berbasis masalah tanpa bantuan software.

\section{SIMPULAN}

Berdasarkan hasil analisis data di atas diperoleh beberapa kesimpulan yang merupakan jawaban atas petanyaan-pertanyaan pada rumusan masalah, diataranya:

1. Peningkatan kemampuan Berpikir Kritis matematis kelompok mahasiswa yang memperoleh pembelajaran metode penemuan terbimbing dengan menggunakan software Geogebra lebih tinggi dibandingkan dengan kelompok mahasiswa yang memperoleh pembelajaran melalui metode penemuan terbimbing tanpa software Geogebra.

2. Tidak terdapat interaksi antara model pembelajaran dengan kemampuan awal mahasiswa terhadap peningkatan kemampuan Berpikir Kritis matematik mahasiswa

3. Untuk meningkatkan hasil belajar mahasiswa, pendidik dapat menggunakan metode penemuan terbimbing dengan software Geogebra sebagai salah satu alternative.

4. Pendidik diharapkan perlu menambah wawasan tentang teori-teori pembelajaran yang lain (pembelajaran yang inovatif), dan dapat menerapkannya dalam pembelajaran.

5. Dalam setiap pembelajaran pendidik harus menciptakan suasana belajar yang memberi kesempatan kepada mahasiswa untuk mengungkapkan gagasangagasan matematika dalam bahasa dan cara mereka sendiri, sehingga dalam belajar matematika mahasiswa menjadi berani berargumentasi, lebih percaya diri, dan kreatif.

\section{DAFTAR PUSTAKA}

Afriati, V. 2011. Peningkatan Berpikir Kritis dan Komunikasi Matematika Siswa dengan Pendekatan Penemuan Terbimbing Berbantuan Software Geogebra. Jurnal Paradikma, 5(1). 
Batubara, I. H. 2017. Peningkatan Kemampuan Berpikir Kritis Matematis Melalui Model Pembelajaran Berbasis Masalah Berbantuan Geogebra Dan Geogebra Di Sma Freemethodist Medan. Journal of Mathematics Education and Science. 3(2): 47-54.

Karnasih, I. 2008. Paper Presentated in International Workshop: ICT for Teaching and Learning Mathematics. Medan: UNIMED

Irawati, H. 2014. Pengaruh Pembelajaran Penemuan Terbimbing terhadap Kemampuan Pemahaman Matematik Siswa. Prosiding Seminar Nasional Pendidikan Matematika Program Pasca Sarjana STKIP Siliwangi Bandung. Volume 1 ISSN 2355-0473

Shadiq, F. 2009. Model-Model Pembelajaran Matematika SMP. Yogyakarta: P4TK Matematika Depdiknas. 